\title{
THE LEGALITY OF CENTRALISED PUBLIC PROCUREMENT IN SOUTH AFRICA
}

\author{
Mitchell Brooks
}

\section{(2016) 3:1 APPLJ 42}

\begin{abstract}
The reform of public procurement at an operational level has been high on the agenda of the South African National Treasury and is illustrated by the incremental introduction of centralised features into the South African procurement system. To ensure lawful reform this paper seeks to determine the legal parameters of centralising the South African procurement system at an operational level by analysing the ruling regulatory framework and case law. This paper clarifies the current challenges faced by South Africa in public procurement taking into account the Annual Reports of Provincial and Local Government as well as material findings of the AuditorGeneral. Further, this paper examines the underlying reasons for centralising and decentralising procurement systems and the practical issues experienced by foreign jurisdictions in implementing such systems as well as its effect on bidding markets. It is proposed that an analysis of the ruling regulatory framework and relevant case law should guide the finding that lawful centralisation is limited and the promulgation of legislation introducing prominent centralised features should be closely scrutinised against the constitutional provisions relating to local government and public finance management.
\end{abstract}




\section{THE LEGALITY OF CENTRALISED PUBLIC PROCUREMENT IN SOUTH AFRICA}

Mitchell Brooks*

LLB (Stellenbosch)

Candidate Attorney, Strauss Daly Attorneys

\section{$1 \quad$ Introduction}

Public procurement refers to the process by which the state obtains goods and services. ${ }^{1}$ Such a process includes identifying goods and services needed, selecting suppliers, contracting and contract management. ${ }^{2}$ Public procurement entails public administration as well as public finance management. As a result, public procurement in South Africa is regulated within a broad legal framework including, amongst others, the Public Finance Management Act 1 of 1999 (PFMA) and the Local Government: Municipal Finance Management Act 56 of 2003 (MFMA). Furthermore, section 217 of the Constitution of the Republic of South Africa, 1996 (Constitution) establishes fundamental principles governing procurement systems across the different spheres of government. Historically, organs of state were required to procure goods and services through the State Tender Board, under which procurement processes were highly centralised. ${ }^{3}$ Subsequently, the enactment of the PFMA and the MFMA resulted in the State Tender Board Act becoming desuetude and accounting officers of government departments were entrusted with procurement processes. This shift to decentralisation was done to democratise the economy and provide access to economic opportunities for previously disadvantaged communities and businesses. Currently, the procurement process continues to operate within a decentralised procurement system in which organs of state are the procuring entities. Within each procuring entity, SCM units carry out procurement. The procurement system is vertically separated between different spheres of government and horizontally

\footnotetext{
* I would like to thank Prof Geo Quinot for his mentorship and his valuable comments on this paper.

1 The South African government uses the term "supply chain management" ("SCM") to refer to the broader scheme of which procurement comprises of.

2 See Quinot \& Arrowsmith 2013:1.

3 State Tender Board Act 86 of 1968.
} 
separated between different institutions. Therefore, each procuring entity has autonomy over the operating of its own procurement system.

This article seeks to determine the legality of an operationally centralised procurement system in South Africa. The incremental introduction of centralised features into our procurement system as well as National Treasury's intention to centralise our system necessitates such a determination. ${ }^{4}$ An example of incrementally centralising features include the Central Supplier Database and the central negotiation of transversal contracts. In 2015, the Office of the Chief Procurement Officer ("OCPO") indicated that it would accelerate the centralisation of common goods and services. ${ }^{5}$ However, the OCPO did not indicate the extent to which it would centralise procurement processes. Therefore, it is imperative to ascertain the legal parameters of centralisation to ensure lawful reforms are undertaken which do not infringe upon the constitutional principles governing the public administration, local government and section 217 of the Constitution.

The legal parameters of this centralisation process will be analysed and discussed in four composite parts. Firstly, this article explores the types of procurement systems to provide the context in which the key drivers for centralisation should be understood. Secondly, this article discusses the key drivers for centralisation and decentralisation. Thirdly, the typical issues surrounding centralisation are discussed by examining foreign jurisdictions that have adjusted towards a centralised system. Fourthly, the constitutionality of a centralised procurement system is scrutinised, thus determining whether any new legislation establishing a centralised system is constitutionally authorised. Finally, this article discusses the impact of centralised procurement on accountability and its compatibility with the relevant provisions of the PFMA and the MFMA.

\section{Procurement systems}

A distinction must be drawn between regulatory functions regarding procurement and operational functions regarding procurement. The regulatory component of procurement involves the monitoring and regulation of procurement operations.

\footnotetext{
4 Minister of Finance South Africa 2016:14-15.

${ }^{5}$ National Treasury 2015:3.
} 
Therefore, the regulatory component of procurement performs an oversight function, whereas operational procurement is the actual acquiring of goods and services. Operational procurement is therefore the implementation of the procurement processes within an established regulatory regime.

\section{Types of procurement systems}

There are two main operational systems in terms of which public procurement can be conducted namely centralised systems and decentralised systems. In a decentralised procurement system, the implementation of procurement is fragmented. For example, a number of public entities across different spheres and levels of government are responsible for the implementation of procurement in South Africa. ${ }^{6}$ In contrast, a centralised procurement system is concentrated and operational powers are vested in one governmental authority to implement procurement on behalf of other public entities. ${ }^{7}$ However, this is not a dichotomous distinction and procurement systems may feature varying levels of centralisation or decentralisation.

\section{Arguments for centralisation}

A centralised system significantly reduces operational costs. The rationale for a centralised system is acquiring goods and services at better value for money and therefore optimising material costs. Thus efficient procurement is the general theme of a centralised procurement system. The state is set to benefit from potential economies of scale by means of volume purchasing or bulk purchasing, enabling the supplier to provide the goods and services at a lower cost. Furthermore, bulk purchasing increases the purchasing power of the state, ${ }^{8}$ enabling the state to negotiate favourable pricing and service level agreements (SLAs). Consequently, higher quality services are procured at a lower cost. In addition, centralisation facilitates opportunities for collaboration in relation to tender and specification development. $^{9}$

A centralised system reduces administrative costs. Centralisation lowers the costs of training personnel within the procurement system. Traditionally, less personnel are

\footnotetext{
${ }^{6}$ Quinot 2013:130.

7 OECD 2000:1 4.

8 OECD 2000:6.

9 Hanks 2008:63.
} 
required in a centralised system and all personnel are centrally located. ${ }^{10}$ As a result, travelling costs are reduced and the training process can be made more efficient and effective by utilising simplified methods. The OECD contends that centralisation promotes attentive contract management and problem resolution as a result of more expert and responsive procurement personnel. ${ }^{11}$

Monitoring and reporting of operations are less burdensome and costly in a centralised procurement system. Centralisation promotes transparency and effective management controls. A central government organisation is better placed to ensure proper recording and reporting of transactions. As a result, transactions are readily verifiable and financial mismanagement becomes easier to detect. Therefore centralisation facilitates a clear audit trail.

Advocates for centralisation argue that a centralised system is better suited for policy procurement addressing social and environmental objectives. A decentralised system is unable to include environmental and social standards and criteria in the procurement process effectively because, for example, implementing green procurement in a decentralised system requires increased technical expertise and awareness. In addition, a decentralised system finds greater difficulty in balancing the interests of local suppliers against green suppliers in comparison to a centralised system. ${ }^{12}$ Therefore it is submitted that centralisation is beneficial to developing green procurement. ${ }^{13}$ The progression of incorporating environmental standards into a procurement system is illustrated by the increasing attention such standards are receiving by other African procurement systems. ${ }^{14}$ In summary, achieving environmental and social objectives proves troublesome in a highly fragmented purchasing system. ${ }^{15}$

\section{Arguments for decentralisation}

\footnotetext{
10 OECD 2000:7.

11 OED 2000:7.

12 Hanks 2008:43.

${ }^{13}$ Green Procurement can be defined as the "purchase of products and services which have less impact on the environment and human health compared with competing products or services that serve the same purpose"; United Nations Development Programme - UNDP, 2008:11.

14 Qionot \& Arrowsmith 2013:380.

15 OECD 2000:7.
} 
Effective procurement, which fulfils the needs of the final user, forms the underlying rationale for decentralisation. ${ }^{16}$ It is easier for the procuring agency to take into account the needs of all the final users when procuring goods and services. This results in refined SLAs that reflect these needs through specific outputs and outcomes to be achieved by the supplier. Refined SLAs reduce the scope for mistakes usually encountered by bulk purchasing. Therefore, a decentralised system is suitable in limiting wasteful expenditure. ${ }^{17}$

Decentralisation promotes competition for state contracts. Trepte suggests that competition operates as a form of discovery for the procuring agent, providing information pertaining to the availability and pricing of goods and services. Therefore, it is vital for procuring agents to ensure competition and contestability to achieve transparent pricing information. ${ }^{18}$ In addition, locally procured goods and services develop the local economy and the growth of small and medium-sized enterprises (SMEs). Local procurement agencies are able to utilise affirmative procurement to support and develop their local suppliers and manufacturers. Furthermore, a decentralised system facilitates Public-Private Partnerships (PPPs), which is an important tool in local economic development and SME development. PPPs promote working relationships between SMEs and local authorities through the provision of public infrastructure and services. ${ }^{19}$ An example of how a decentralised procurement system facilitates PPPs supporting SMEs can be illustrated by the City of Cape Town's PPP with the Central City Improvement District, a Non-Profit Company incorporated by a large group of SMEs within the precinct. This Non-Profit Company works in partnership with the City of Cape Town in providing supplementary urban management services to parts of the Cape Town central business district. ${ }^{20}$ The CCID illustrates a willingness of businesses to engage government at a local level to find solutions to their service delivery needs using innovative methods. The success of the CCID can be attributable to the approachability of local government and the ability for both parties to communicate effectively as a result of their geographical location.

\footnotetext{
16 OECD 2000:4.

17 OECD 2000:8.

18 Trepte 2007: ch 7.

19 Kakwambi 2012:26.

20 Cape Town Central City Improvement District, 2015.
} 
Decentralisation prevents corruption and promotes accountability. Such a system reduces the possibility of specific suppliers receiving unfair preferential treatment from a centralised procuring agent. The OECD argues that this lack of large-scale protectionism reduces incentives for corruption. ${ }^{21}$ Furthermore, local officials are responsible for procurement and can be held to account in decentralised systems. In contrast, members of the public may be reluctant to entrust distant and unapproachable officials in a centralised system.

Finally, decentralised procurement facilitates certain logistical advantages. Contracts awarded to suppliers usually include the obligation to physically deliver the specified goods to the final user. In contrast, a centralised procurement system may utilize bulk delivery and warehousing as the default approach. Typical issues related to bulk delivery include difficulties in identifying shortages, the impact of amending orders and the fast-tracked delivery of materials. ${ }^{22}$ These issues often only manifest on site and create further unexpected costs. As a result, inventory management and distribution planning become large-scale and more complex. ${ }^{23}$ This is likely to result in further costs and problems as the procurement process requires the co-ordination of multiple parties. Alternatively, the contract will have to additionally provide for distribution, with potentially increased costs implications.

\section{Supply chain management performance}

In light of the above theoretical advantages and disadvantages, it is imperative to assess a procurement system practically. The below assessment will give practical meaning to the procurement system, without which assessment, such systems may become the elusive bearer of false comfort. This is because the shortcomings experienced in a procurement system may largely derive from its implementation. South Africa is an example of a procurement system facing external challenges incorrectly attributed to the procurement system itself. Instead, it is submitted that the South African procurement system mitigates and aggravates certain risks attaching to its implementation, of which properly formulated policies and directives may guard against such risks. The risks of corruption, non-compliance, overspending and

\footnotetext{
21 OECD 2000:8.

22 Clark and Lorenzoni 1997:222.

23 Sharma 2009:138.
} 
wasteful expenditure have manifested into practical challenges faced by South African supply chain managers. The challenges relevant to the procurement system are set out hereunder.

\section{Provincial and local challenges relating to the procurement system}

The annual reports of the provincial treasuries indicate a number of challenges encountered in SCM implementation in South Africa, particularly the Limpopo, NorthWest and the Eastern Cape provinces. The Eastern Cape provincial treasury experienced difficulties in complying with advertising requirements resulting in an irregular expenditure of R1,3 million. ${ }^{24}$ The Limpopo provincial treasury achieved 55\% compliance with SCM prescripts, ${ }^{25}$ highlighting a lack of skilled personnel as an issue. Furthermore, municipalities are experiencing challenges in SCM, often requiring intervention from the provinces. For example, multiple municipalities in Kwa-Zulu Natal (KZN) required intervention by the $\mathrm{KZN}$ SCM Unit, including the Ugu District Municipality. ${ }^{26}$ The Annual Report of the Ugu District Municipality reveals that the municipality was non-compliant with the disclosure and conflict of interest requirements of section 112(j) of the MFMA and SCM Regulation 13(c). Furthermore, bids were not consistently adjudicated by committees composed in accordance with SCM regulations. ${ }^{27}$ Lastly, the municipality's lack of evidence and record keeping of compliance with the invitation and adjudication processes necessitated provincial intervention. Such interventions included direct assistance in managing procurement processes.

Overall, the Auditor-General made material SCM findings in 185 municipalities (66\%). ${ }^{28}$ The Auditor-General highlights a number of reasons for these material findings. Firstly, 76 municipalities (28\%) failed to achieve adequate contract management due to a lack of contract monitoring and weak controls. ${ }^{29}$ Secondly, vacancies and instabilities were experienced in key SCM unit positions such as the municipal manager and chief financial officer. ${ }^{30}$ Thirdly, the Auditor-General highlights

\footnotetext{
24 Eastern Cape Provincial Treasury 2015:105.

25 Limpopo Provincial Treasury 2015:43.

26 Auditor-General 2015:33.

27 Auditor-General 2015:125.

${ }^{28}$ Auditor-General 2015:29.

${ }^{29}$ Auditor-General 2015:36.

30 Auditor-General 2015:18.
} 
continued non-compliance with SCM legislation as the main reason for increased irregular expenditure. ${ }^{31}$ In 2014/2015 SCM amounted to $100 \%$ of the irregular expenditure incurred by the four worst performing municipalities. ${ }^{32}$

In summary, the fundamental problem experienced in South Africa's decentralised system is a lack of trained procurement practitioners. As a result, many municipalities lack the capacity to perform their own SCM. This lack of capacity results in noncompliance with procurement processes. Corruption is a further issue experienced throughout the decentralised system as a number of provincial treasuries are undergoing investigations regarding corrupt practices. As a result of these challenges, fruitless and wasteful expenditure for the 2014/2015 year amounted to R1,34 billion, more than R1 billion higher than in 2010/2011 and irregular expenditure amounted to R14,75 billion, more than twice that of 2010/2011. According to the Auditor-General, Free State, Eastern Cape, North West, Mpumalanga and Limpopo are the main contributors to this increase. ${ }^{33}$

\section{National challenges relating to the procurement system}

National Treasury raises a number of key challenges which provide useful insight as to what the national government believes is flawed in the current procurement system. National Treasury highlights a lack of purchasing power and failing to obtain value-formoney goods and services as their main challenge in public procurement. Treasury blames the decentralised and fragmented system as the sole cause of this. ${ }^{34}$ Issue is taken with the SCM organisational structures, suggesting that the current structures amplify existing issues regarding unskilled personnel. ${ }^{35}$ Furthermore, it is suggested that favouritism and collusion amongst suppliers emanate from a lack of understanding between the fragmented procuring agencies and the private sector. ${ }^{36}$ National Treasury indicates that the fragmentation of processes and systems makes SCM compliance difficult. Currently, 40 contracts are centrally negotiated for the sole purpose of reducing costs, utilising economies of scale. This justification for centrally

\footnotetext{
${ }^{31}$ Auditor-General 2015:17.

32 Auditor-General 2015: 33.

33 Auditor-General 2015:17.

${ }^{34}$ National Treasury 2015:3.

35 National Treasury 2015:4.

36 National Treasury 2015:6.
} 
negotiated contracts suggests that reducing wasteful expenditure is the primary rationale for National Treasury moving towards a centralised procurement system. ${ }^{37}$ Furthermore, the Auditor-General recommends that Treasury must focus on the centralisation of procurement, an initiative flowing from the Office of the Chief Procurement Officer (OCPO). ${ }^{38}$ This illustrates that government considers centralisation to be the solution to the current challenges experienced in SCM.

\section{Issues surrounding centralisation}

\section{The supply market}

Centralisation has a negative effect on the external market. The size of public procurement contracts constitutes an obstacle for SMEs. Evidence suggests that fewer SMEs bid for larger procurement contracts. ${ }^{39}$ Centralisation of procurement tends to result in a centralisation of the pool of suppliers. Consequently, SMEs find it difficult to enter the market for public procurement because they tend to lack the supply capabilities required to perform the central contract. ${ }^{40} \mathrm{~A}$ centralised procuring state such as Bulgaria, for example, has seen a large proportion of state contracts being awarded to a small pool of large companies. ${ }^{41}$ This concentration of suppliers has resulted in corruption and collusion. Therefore centralisation has created major issues for Bulgarian public procurement. The Irish SME Association argues that the state generally requires a greater level of detail from bidders for centralised contracts. Details relating to business turnover and previous project values have a discriminatory effect on SMEs, increasing the barriers to entry in the public procurement sector. ${ }^{42}$ Irish SMEs argue that the bidding process for smaller contracts, through their centralised system, is too bureaucratic, complex and costly for SMEs. ${ }^{43}$ Therefore centralisation tends to reduce competition for state contracts.

The market is affected by procurement regulations. Centralised agencies tend to unintentionally regulate the market due to standardised specifications, contractual conditions and strategic sourcing. This increased role as a market regulator raises

\footnotetext{
37 National Treasury 2016:3.

38 Auditor-General 2015:70.

39 Phillips, Harland \& Telgen 2008:54.

40 Karjalainen 2009:44.

${ }^{41}$ European Commission on Enterprise \& Industry 2014:8.

42 ISME 2013:8.

43 ISME 2013:6.
} 
concerns in relation to suppliers that have been excluded from contracts and framework agreements of the centralised agency. ${ }^{44}$ Consequently, suppliers will exit the market, particularly SMEs. The question is whether a centralised procurement agency has the legitimacy to undertake market regulation functions. ${ }^{45}$

\section{Pricing and co-operation}

Centralisation promotes short-term savings but does not sustain competitive pricing. Although theoretically it is widely accepted that centralising procurement results in significant savings, there is limited research as to how to calculate the cost effects of transitioning to a centralised system. ${ }^{46}$ There has been debate as to the difficulty of measurement and reporting on the costs associated with centralised procurement. Discourse suggests that there is major potential for overstating or understating costs in such a system. ${ }^{47}$ The supply and demand theory indicates that a reduction of the supply market results in higher average pricing. Therefore an increase in the average pricing of state tenderers is a natural occurrence in a market economy. Furthermore, centralisation will only bring savings if internal compliance is prioritised, irregular expenditure is reduced and specified contractual terms are utilised strictly. ${ }^{48}$ Research suggests that non-compliant purchases increase during the early stages of centralisation as a result of personnel being unfamiliar with the system and internal compliance procedures. ${ }^{49}$ Notably, electronic procurement has been identified as an effective means of reducing non-compliant purchasing under these circumstances. ${ }^{50}$

Co-operation amongst the various role players in a procurement system becomes difficult in a centralised system. The centralised procurement system in Hungary for example, experiences issues pertaining to cooperation between suppliers and the central procurement agency. In a state comprising a high amount of SMEs, few engage directly with the central procurement agency. Generally, the process of centralisation in South Africa has given rise to important practical problems. Centralisation in the environmental sector has illustrated that officials are unwilling to

\footnotetext{
44 Graells 2016:30.

45 Graells 2016:30.

46 Karjalainen 2009:4.

47 Leenders 1998:336.

48 Karjalainen 2009:5.

49 Karjalainen 2009:12.

50 Karjalainen 2009:252.
} 
co-operate with such a process in what has been described as 'turf wars' between governmental departments. ${ }^{51}$

\section{The constitutionality of centralisation}

Public procurement is governed by the Constitution. Accordingly, it is imperative for a centralised procurement system to promote a number of constitutional principles. The typical issues surrounding centralisation, as discussed above, play an important role in assessing compliance with section 217 and the public administration principles in particular. Furthermore, the constitutionally envisaged principles of separation of powers and co-operative governance must be analysed with reference to recent case law to determine the legal parameters of centralisation. If a centralised procurement system fails to promote these constitutional principles, any legislation centralising the procurement system will be unauthorised and unconstitutional. However, to determine the constitutionality of a centralised procurement system it is necessary to illustrate how organs of state across the different spheres of government derive their procurement powers from the Constitution.

\section{Empowering provision}

Section 217 of the Constitution specifically regulates procurement in South Africa. Section 217(1) states:

"When an organ of state in the national, provincial or local sphere of government, or any other institution identified in national legislation, contracts for goods or services, it must do so in accordance with a system which is fair, equitable, transparent, competitive and cost-effective." 52

Steenkamp NO v Provincial Tender Board, Eastern Cape ${ }^{53}$ (Steenkamp) initially identified the above section as the source of the State Tender Board's procurement powers and functions. However, the court qualified this statement in stating:

\footnotetext{
${ }^{51}$ Du Plessis 2008:87.

52 The Constitution s 217(1).

532007 (3) SA 121 (CC) para 33.
} 
"[Section 217] lays down that an organ of state in any of the three spheres of government, if authorised by law, may contract for goods and services on behalf of government." ${ }^{54}$

Steenkamp was later better explained by the Constitutional Court in Allpay Consolidated Investment Holdings (Pty) Ltd and Others $v$ Chief Executive Officer of the South African Social Security Agency and Others ${ }^{55}$ (Allpay). Allpay provides that section 217 sets the minimum requirements to be met in the tender process and the subsequent contracts entered into. ${ }^{56}$ As a result, it is generally accepted that section 217 is the source of public procurement regulation, but not procurement powers. ${ }^{57}$ Although section 217 of the Constitution is not the source of public procurement powers, it is submitted that the Constitution by implication grants organs of state, in the three spheres of government, the power to procure goods or services and schedules 2 and 3 of the PFMA merely attempt to limit these powers.

\section{Authorisation of local government}

If it is accepted that section 217 does not confer any powers to procure, the powers of local and provincial spheres of government to procure are found elsewhere in the Constitution. The wording of section 217(1) appears to assume an existing capacity to contract, which is qualified by specific requirements. ${ }^{58}$ It is submitted that the Constitution confers this capacity to contract upon organs of state in at least the local sphere of government.

The point of departure is that the authority of municipalities to procure goods and services derives from section 156 of the Constitution. Section 156 provides that municipalities have the executive authority and the right to administer local government matters listed in Part B of schedules 4 and 5 of the Constitution. Therefore, and by implication, procurement concerning matters not listed in Part B of schedules 4 and 5 may be operationally centralised. Part B of schedules 4 and 5 lists a number of areas including, but not limited to, municipal roads and municipal health

\footnotetext{
54 Para 33.

55 [2013] ZACC 42 para 31.

56 Para 32.

57 Quinot 2014:16.

58 Quinot 2009:42.
} 
services. The mechanisms available to realise these constitutionally mandated functions are open-ended and will include public procurement. Although procurement is not explicitly referenced in the schedules, it cannot be argued that it constitutes a 'residual matter' and thus an exclusive national competence. Such an argument is irreconcilable with the current decentralised system. Furthermore, section 156(5) confers upon municipalities:

"the right to exercise any power concerning a matter reasonably necessary for, or incidental to, the effective performance of its functions." ${ }^{59}$

It is submitted that it is reasonably necessary or incidental for municipalities to undertake procurement operations in order to effectively perform their functions. ${ }^{60} \mathrm{In}$ other words, it is reasonably necessary for a municipality to have the ability to procure services in order to perform effectively in the functional area of "municipal roads." However, the complexity of the procurement system complicates the abovementioned submission and it is necessary to determine what elements of procurement are necessary to perform municipal functions effectively. Firstly, the determination of the specifications of a tender will consist of identifying the need for services and the scope of the services in order to fulfil a specific function on behalf of a municipality. In addition, the municipal budget largely influences the specifications process. To centralise the specifications process appears to undermine a municipality's ability to address community specific needs as a central entity may overlook such needs. Furthermore, it is unclear as to what extent national government will be able to perform this function in accordance with a municipal budget. Specifications processes occur frequently, often determining the feasibility of a municipality pursuing a tender and to delegate this function to a central entity will inevitably overload that central entity with work that may not materialise into actual service delivery.

Secondly, a municipality controls the invitation process of a tender. The 2017 Preferential Procurement Policy Framework enables tendering entities to include minimum qualification criteria in their invitations to tender. Minimum qualification criteria will inherently have the ability to exclude a large pool of bidders from the tender process. For example, minimum BBB-EE levels, if applied uniformly across different

\footnotetext{
59 The Constitution s 156(5).

${ }^{60}$ Education \& Training Unit (ETU) For Democracy \& Development, 2006.
} 
municipalities, may be detrimental to local service providers as the demographics in the Stellenbosch Municipality may vastly differ to Msunduzi Municipality. A further element of the invitation process is that of briefing sessions, which are held to inform suppliers and address queries. Should the specifications process be centralised the ability of the municipality to conduct compulsory briefing sessions for suppliers may be difficult as local officials become too far removed from the procurement process. A further problem in centralising the invitation process will be the collection of bid documents, which will need to be transported to the central entity if the adjudication process is centralised. This transportation process increases the costs of procurement as well as the risk of irregularities should an incident take place during transit. A possible solution to this problem may be the electronic submission of bids through an eTender Portal System.

Thirdly, the adjudication process is conducted in two phases comprising of the bid evaluation and bid adjudication. Arguably, this process may be centralised without issue save for the transportation of bid documents. It is submitted that the centralisation of this process may have a significant impact of streamlining the adjudication process and reducing the risks of irregularities as applying a uniform set of rules to one adjudication body is easier to monitor and implement. It is submitted that the management of this element of procurement by a municipality is not necessary to the municipality in carrying out its functions. This is because the outcome of a bid adjudication is merely a recommendation. The Accounting Officer of the municipality, the Municipal Manager, is still the decision-maker in awarding the tender.

Lastly, a central entity may award a tender without issue, however, a problem arises when a Service Level Agreement ("SLA") must be concluded between the supplier and the municipality's Accounting Officer. By signing the SLA, the Accounting Officer accepts full responsibility for the SCM process despite the fact that most of the SCM processes may have been conducted by a central entity beyond the Accounting Officer's oversight. The impact of this oddity is set out under heading 5 below.In assessing the authority of local government, section 152 of the Constitution lists the sustainable provision of services to communities as an object of local government. The enactment of the MFMA gives effect to these constitutionally enshrined objects of local government. Section 111 of the MFMA provides that each municipality and 
municipal entity must have and implement a supply chain policy. Further, the autonomy of local government is secured by section 115 designating the accounting officer of the municipality as the official responsible for the implementation of SCM policy. Furthermore, the accounting officer is responsible for the enforcement of agreements procured through SCM policy. Therefore the MFMA suggests the Accounting Officer has complete authority over SCM processes. The above illustrates the inherent ability of local government to operationally undertake procurement in order to achieve their constitutional objectives.

The Constitution recognises this link between service delivery and decentralised procurement. Section 156(4) instructs the national and provincial government to decentralise operations where the decentralisation of the administration of a function to a municipality facilitates better service delivery. Depending on the circumstances and the degree of centralisation of procurement operations certain interventions or reforms may amount to an interference with local government. Section 118 of the MFMA prohibits the interference with the SCM system of a municipality by any person. Although section 155(7) of the Constitution enables national and provincial intervention in municipal functional areas by means of regulating their authority, such intervention is extremely limited. Therefore national government may regulate municipal procurement powers but they may not usurp those powers, except in terms of section 44 and section 139 of the Constitution. Section 66 of the PFMA echoes this proviso with reference to National Treasury.

\section{Centralisation and the section 217 principles}

A centralised procurement system will need to be legislated by Parliament. Procurement legislation must give effect to the provisions of section 217 of the Constitution to pass constitutional muster. Therefore the centralising legislation must promote the established principles of public procurement. The principles governing a procurement system are fairness, equitableness, transparency, competitiveness and cost-effectiveness. These five principles must be balanced in order to establish a constitutionally compliant procurement system. ${ }^{61}$

${ }^{61}$ Bolton 2007:56. 
The position regarding fairness in the context of public procurement is debated to be either procedural fairness only or both procedural and substantive fairness, ${ }^{62}$ yet the preferred interpretation is to include both aspects of fairness. ${ }^{63}$ Procedural fairness encapsulates key indicators such as access to tenders, availability of rules and procedures as well as the provision of opportunities for tenderers to participate. ${ }^{64}$ Furthermore, equality of treatment is important for a fair procurement system. The procuring entity must treat tenderers equally and should not show bias or advantage one tenderer over the other. ${ }^{65}$ Therefore, equitableness is inextricably linked to the principle of fairness. In brief, equity has been referred to by our courts as 'substantive equality' and in the context of section 217 equity refers to the advancement of previously disadvantaged groups using public procurement. ${ }^{66}$ The Preferential Procurement Policy Framework Act 5 of 2000 (Procurement Act) provides insight in relation to substantive equality in procurement. The Procurement Act describes substantive equality as allowing preferential procurement policy to include the goal of contracting with categories of persons previously discriminated against based on gender, race or disability. ${ }^{67}$ Transparency requires an open and public procurement system, in which information is public and readily available, and the procurement process is conducted in an open manner. Competitiveness is inextricably linked with cost-effectiveness as the greater the level of competition, the greater the likelihood of achieving value-for-money goods and services, in other words cost-effectiveness. ${ }^{68}$

As discussed above under heading 3, a centralised system may promote costeffectiveness in the short-term. However, due to the negative impact on long-term competition, long-term cost-effectiveness is hampered by a centralised system. Furthermore, concerns have been raised regarding the fairness and equitableness of a centralised system by SMEs. This is problematic as section 195(1)(c) and (d) of the Constitution requires the public administration to be development-orientated and provide services impartially, fairly and equitably. Considering that public procurement in South Africa is used as a policy tool to drive economic development, innovation and

\footnotetext{
62 Bolton 2007:47.

63 De la Harpe Procurement Law 276.

64 Bolton 2007:48.

65 Bolton 2007:47.

66 Harksen v Lane 199711 BCLR 1489 (CC) para 53.

67 Preferential Procurement Policy Framework Act 5 of 2000 s 2(1)(d)(i).

68 For a more in-depth discussion of the section 217 principles, see Bolton 2007:42-56.
} 
transformation, ${ }^{69}$ it is doubtful whether prioritising short-term cost-effectiveness promotes these constitutionally mandated initiatives.

\section{Co-operative governance}

\section{Constitutional mandate}

Chapter 3 of the Constitution explicitly makes provision for co-operative governance. Section 40 establishes the three spheres of government as distinctive, interdependent and interrelated. As discussed above, each sphere has their own executive powers over their functional areas and matters reasonably necessary or incidental to those functions, including procurement. Furthermore, section 41 of the Constitution provides a number of co-operative governance principles that must be promoted by all spheres of government and organs of state. The Constitution requires the aforementioned parties to respect the constitutional powers and functions of government in other spheres, to not assume powers or functions not constitutionally conferred upon them and to not encroach on the geographical, functional or institutional integrity of another sphere. ${ }^{70}$ Above all, an Act of Parliament must foster intergovernmental relations. ${ }^{71}$ Currently, the Constitution enables provincial and national spheres of government to delegate their functions to municipalities by agreement. However, the municipality implements the function under the authority and direction of the delegating authority. There is no express provision in the Constitution that enables a municipality to delegate a function by agreement to the provincial or national spheres of government. Instead, the provincial sphere of government can only intervene in the local sphere of government where it fails to fulfil an executive obligation. ${ }^{72}$ Interestingly, section 76(b) of the Local Government: Municipal Systems Act 32 of 2000 ("the Municipal Systems Act") provides for the contracting out of municipal services to an external party. More importantly, the section 217 principles read together with section 14(5) of the MFMA are not applicable to instances where a municipality decides to make use of another organ of state to deliver municipal services. However, section $76(b)$ of the Municipal Systems Act requires any delegation to be initiated by the municipality and therefore delegation may only occur where the municipality seeks to delegate the municipal

\footnotetext{
69 Bolton 2006:193.

${ }^{70}$ See the Constitution s $41(\mathrm{e})-(\mathrm{g})$.

${ }^{71}$ See the Constitution s $41(2)$.

72 See the Constitution s 139.
} 
service and any attempt to coerce an upstream delegation by an upstream sphere of government will amount to interference.

\section{Usurpation of powers}

As discussed above, challenges are faced in procurement across the different spheres of government resulting in poor service delivery. Consequently, national and provincial spheres of government have attempted to intervene in the functional areas of local government in terms of section 155(7) of the Constitution. Section 155(7) of the Constitution confers legislative and executive authority upon National and Provincial government to ensure local government performs its functions effectively. However, the purpose of section $155(7)$ is to promote service delivery in conjunction with cooperative governance and not to undermine co-operative governance. Therefore legislation that centralises operational procurement functions cannot be promulgated under the guise of section 155(7). According to Cameron J section 155(7) is limited to establishing norms and guidelines enabling municipalities to exercise a power or perform a function. ${ }^{73}$ Cameron $\mathrm{J}$ relies on the text "see to the effective performance of functions by municipalities" in reaching his interpretation. ${ }^{74}$ Therefore, section $155(7)$ does not empower national or provincial government, by legislation, to perform a function itself and usurp executive municipal powers. ${ }^{75}$ Arguably, this judgment may invalidate an attempt to establish a national or provincial body to meru moto override procurement decisions by local government on appeal, although a review process will be permissible. Furthermore, Tronox KZN Sands (Pty) Limited $v$ KwaZulu-Natal Planning And Development Appeal Tribunal (Tronox) indicates that legislation providing a mechanism compelling municipalities to allow appeals from their decisions where a municipality may not deem it so desirable will be unconstitutional. ${ }^{76}$

Co-operative governance can be difficult to understand where there is confusion concerning the distribution of powers across the spheres of government. This

\footnotetext{
${ }^{73}$ Minister of Local Government, Environmental Affairs and Development Planning, Western Cape v The Habitat Council; Minister of Local Government, Environmental Affairs and Development Planning, Western Cape v City of Cape Town 20144 SA 437 (CC) para 22.

74 The Constitution s 155(7).

${ }^{75}$ Minister of Local Government, Environmental Affairs and Development Planning, Western Cape $v$ The Habitat Council; Minister of Local Government, Environmental Affairs and Development Planning, Western Cape $v$ City of Cape Town 20144 SA 437 (CC) para 21.

76 Tronox KZN Sands (Pty) Limited v KwaZulu-Natal Planning and Development Appeal Tribunal 2016 JDR 0179 (CC) para 11.
} 
confusion extends to our courts. Davis J, in Maccsand (Pty) Ltd v City of Cape Town (Maccsand), ${ }^{77}$ questions the concept of exclusive national competence in suggesting that nothing precludes the possibility of an overlap between the powers of national and local government. Davis $\mathrm{J}$ bases this argument on the obiter of Wary Holdings (Pty) Ltd v Stalwo (Pty) Ltd (Wary Holdings), ${ }^{78}$ where the court suggests that two spheres of government can exercise overlapping control over the subdivision of agricultural land, listed in Part A of Schedule 4 of the Constitution, even to the extent of vetting each other's decisions. Although not expressly stated, it appears that the court in Wary Holdings refers to an overlap of powers from the same perspective. However, the dissenting judgment of Yacoob J, in Wary Holdings, rejects this overlap and is to be preferred in light of constitutional imperatives relating to co-operative governance. Yacoob $\mathrm{J}$ states that the retention of the power to approve sales and applications of land rezoning is inconsistent with the constitutional mandate to restructure, decentralise and democratise power. ${ }^{79}$ Humby seems to support Yacoob J's position in characterising schedules 4 and 5 of the Constitution as not only providing for the distribution of powers, but also the reservation of powers to a particular sphere of government. ${ }^{80}$ The Constitutional Court in Maccsand held that local government had not usurped the powers of national government. This finding was not because both pieces of legislation regulated the same subject matter (mining), but rather because each piece of legislation did not purport to achieve the purpose of the other. Instead, the sphere of control intended to operate from different perspectives with different objects. ${ }^{81}$ Therefore spheres of government can act on the same subject matter from different perspectives, and the implementation by one sphere may be dependent on the consent of the other. This does not amount to an overlap as an overlap may constitute a usurpation of powers.

Humby argues that a usurpation of powers will occur where:

\footnotetext{
7720106 SA 63 (WCC) para 43.

78 Wary Holdings (Pty) Ltd $v$ Stalwo (Pty) Ltd and Another (CCT78/07) [2008] ZACC 12 para 80.

${ }^{79}$ Wary Holdings (Pty) Ltd v Stalwo (Pty) Ltd and Another (CCT78/07) [2008] ZACC 12 para 137.

80 Humby 2012:631.

${ }^{81}$ Maccsand (Pty) Ltd v City of Cape Town 20127 BCLR 690 (CC) para 46.
} 
"[O]ne sphere of government [exercises] the executive power of another sphere and attempts to operate from the same functional perspective as the encroached sphere in relation to an object of power." 82

In City of Johannesburg Metropolitan Municipality v Gauteng Development Tribunal and Others, ${ }^{83}$ the Constitutional Court confirmed an interpretation of "municipal planning," a functional area listed in Part B of Schedule 4, and found that legislation assigning administrative and decision-making powers to a provincial body, therefore operational powers, relating to rezoning and town planning was unconstitutional and thus invalid. In summary, the duplication of powers in Maccsand was permissible because the national sphere of government operated from a functional perspective distinct to "municipal planning." 84 In the case of public procurement, the question is whether a centralised procurement body would be operating from a perspective distinct to "municipal roads" In order for a central entity to undertake the procurement operations of a municipality, the central entity will need to approach the functional area of municipal roads from a different perspective and purpose to the municipality. A municipality approaches the functional area of municipal roads from the perspective of service delivery insofar as the municipality is concerned with delivering a completed road. Arguably, national government may approach this subject matter from the perspective of cost-effectiveness insofar as potentially procuring bulk elements of which the completion of the road is dependent on, i.e. cement. The national perspective is problematic when read with section 112 of the MFMA which suggests that the national perspective is completely subsumed by the municipal perspective. Section 112 of the MFMA suggests that the SCM policy of a municipality is geared towards fairness, equitableness, transparency and cost-effectiveness. Therefore any attempt by national government to approach the procurement of goods or services facilitating the service delivery of a functional area from a perspective related to costeffectiveness constitutes an overlap. However, there is a possibility of limited centralised procurement where the procurement is incidental to two distinct functional areas assigned to the national and local sphere of government. For example, the distinction between "provincial planning" and "municipal planning" may be difficult to

\footnotetext{
82 Humby 2012:637.

8320109 BCLR 859 (CC).

84 Humby 2012:637.
} 
determine in practice. In fact, Jaftha J has described these functional areas as "not being contained in hermetically sealed compartments but they nevertheless remain distinct." 85 Jaftha $\mathrm{J}$ suggests that the contents of national, provincial and local government functions may overlap. Therefore it seems that a municipality opposing central procurement implemented on the basis of overlapping functional areas may only rely on the minority judgment of Yacoob in Wary Holdings. However, a series of judgments have demarcated the content of municipal functional areas first and have held that the provincial or national functional area includes everything outside of the municipal functional area. ${ }^{86}$ The prior demarcation of a municipal functional area and the subsequent finding that the provincial functional area constitutes something different lowers the probability of an overlap in content. According to Van Wyk the generally accepted position of our courts is that municipal planning includes all functions that have an intra-municipal impact whereas provincial planning includes all functions that have an extra-municipal impact. If this generally accepted position is applied to our "municipal roads" example, a municipal road linking two district municipalities may be centralised to a provincial entity. ${ }^{87}$ However, Van Wyk fails to elaborate on the position where the functions have an extra-municipal impact on local municipalities but an intra-municipal impact on a single district municipality. It is submitted that in such a situation, the district municipality housing the two local municipalities may procure the goods and services necessary to construct the municipal road between its two local municipalities.

The Constitutional Court in Tronox held the relevant legislation to be unconstitutional because the legislative scheme diluted the exclusive competence of the municipality and it allowed the province to interfere without taking into account the municipal operations, objectives, budget and resources. ${ }^{88}$ Tronox confirms Gauteng Development Tribunal insofar as the word "municipal" and "provincial" have distinct

\footnotetext{
${ }^{85}$ City of Johannesburg Metropolitan Municipality v Gauteng Development Tribunal and Others 2010 9 BCLR 859 (CC) paras 54-55.

${ }^{86}$ City of Johannesburg Metropolitan Municipality v Gauteng Development Tribunal and Others 2010 2 SA 554 (SCA) para 31; City of Johannesburg Metropolitan Municipality v Gauteng Development Tribunal and Others 20109 BCLR 859 (CC) paras 62-63.

87 Van Wyk 2012:314.

88 Tronox KZN Sands (Pty) Limited v KwaZulu-Natal Planning and Development Appeal Tribunal 2016 JDR 0179 (CC) para 18.
} 
meanings in spite of them sharing the term "planning". ${ }^{89}$ Tronox goes further in providing that local government has the autonomous power to manage municipal planning which cannot be intruded on under any circumstances. ${ }^{90}$ Importantly, the fact that parties argued on the basis that the appeal body was independent did not render Habitat Council inapplicable. ${ }^{91}$ The mere fact that municipalities are subjected to an appeal process by the province constitutes an intrusion of their powers. Therefore, following the Tronox approach, if public procurement for example falls within the functional area of "municipal roads," the power to manage municipal roads and procurement by implication, may not be intruded on under any circumstances. In light of the above and as a matter of prudence, in order to avoid intruding on local government's powers and functions, procurement may be centralised when the following requirements are met sequentially:

1. the content of the central entity's functional area overlaps with the content of the local government's functional area;

2. the central entity serves to achieve, through its procurement, a purpose distinct to that of local government;

3. procurement that has an intra-municipal impact may not be centralised whereas procurement that has an extra-municipal impact may be centralised;

4. procurement resulting in an extra-municipal impact between two local municipalities common to a district municipality may only be centralised to that district municipality;

Arguably, at provincial or national level, certain bulk materials that are common to multiple municipalities' procurement projects may be centrally procured through a provincial or national transversal contract on the basis that:

a. the content of the central entity's functional area overlaps with the content of the local government's functional area (ie. health services

89 Tronox KZN Sands (Pty) Limited v KwaZulu-Natal Planning and Development Appeal Tribunal 2016 JDR 0179 (CC) para 20.

90 Tronox KZN Sands (Pty) Limited v KwaZulu-Natal Planning and Development Appeal Tribunal 2016 JDR 0179 (CC) para 28.

91 Tronox KZN Sands (Pty) Limited v KwaZulu-Natal Planning and Development Appeal Tribunal 2016 JDR 0179 (CC) para 28. 
and municipal health services in respect of the procurement of Antiretroviral medication or municipal roads and provincial public works in the respect of the procurement of cement);

b. the impact of the procurement is extra-municipal;

C. the bulk procurement of common goods is necessitated by a purpose distinct to that of each individual municipality as the central entity must act in the national or provincial interest and not simply because transversal contracts are cost-effective; ${ }^{92}$

d. the procurement of common materials does not amount to or undermine the management of the municipal procurement system.

\section{Constitutional amendment}

Tronox emphasises the rationale for the Constitution allocating exclusive power to municipalities. The Constitutional Court states:

"[Municipalities] are more likely to be sensitive to their own integrated planning strategies and are thus better placed to make decisions concerning land use and development." 93

It is submitted that according to the above remark by the Constitutional Court, integrated planning strategies (IPS) and public procurement are as inextricably linked as land use and IPS. This is because IPS facilitate service delivery by municipalities by means of identifying necessary services, providing cost-effective methods for providing services, stakeholder engagement and specific key performance indicators. ${ }^{94}$ Consequently, there appears to be constitutional authorisation for each sphere of government to undertake procurement operations at their respective levels and any unlawful attempt to interfere with this power may amount to a usurpation of powers. In addition, the constitutional principles governing public administration may potentially be undermined in a significantly centralised procurement system. In

\footnotetext{
92 National Treasury, 2003.

93 Tronox KZN Sands (Pty) Limited v KwaZulu-Natal Planning and Development Appeal Tribunal 2016 JDR 0179 (CC) para 57.

94 Education \& Training Unit (ETU) For Democracy \& Development, 2006.
} 
pursuance of clarity, the Constitution should be amended to authorise a degree of centralised procurement, at least for common goods, by either inserting an unambiguous empowering provision in section 217 or inserting procurement as a functional area in schedule 5 . The latter will require a special majority of $75 \%$ by the provincial legislatures. ${ }^{95}$

\section{Impact on accountability: the PFMA and MFMA}

Section 38(1)(a)(iii) of the PFMA designates the accounting officer of the department, trading entity or constitutional institution as the responsible official for ensuring and maintaining an appropriate procurement and provisioning system that echoes the section 217 principles. The PFMA requires the accounting officer, inter alias, to prevent irregular expenditure, manage resources and control the budget of the department or entity. Furthermore, the accounting officer may delegate any power conferred by the PFMA, however the accounting officer maintains full accountability. ${ }^{96}$ Similarly, section 115 of the MFMA designates the accounting officer of the municipality as the responsible official for the implementation of SCM policy.

The PFMA imposes fiduciary duties on the accounting authorities including a duty of utmost care as well as a duty to act with honesty, fidelity and in the best interests of the entity. ${ }^{97}$ Section 83 of the PFMA further provides that accounting authorities will be jointly and severally liable for negligently breaching their fiduciary duties. Importantly, section 86 imposes criminal liability, and possible imprisonment, on accounting officers if that official wilfully or grossly negligently fails to ensure and maintain an appropriate procurement system or perform their fiduciary duties. The MFMA provides similar provisions relating to fiduciary duties and liability. ${ }^{98}$

It should be noted that section 3(3) of the PFMA expressly provides for its prevalence in instances of conflict with any other legislation. Therefore, legislation that centralises the procurement system will need to amend the PFMA and the MFMA to divest the

\footnotetext{
${ }^{95}$ Ex parte Chairperson of the Constitutional Assembly: in re Certification of the Constitution of the Republic of South Africa 199619964 SA 744 (CC) para 232.

96 See the PFMA s 44.

97 See the PFMA S 51(a) - (d).

${ }^{98}$ See the MFMA s 61.
} 
accounting officer of its procurement duties or indemnify the accounting officer against responsibility and liability in a centralised procurement system.

\section{Conclusion}

States are able to combine different features of centralised and decentralised procurement systems. In essence, a state's type of procurement system can be placed along a spectrum between being fully decentralised and fully centralised. However, the South African legal framework limits the degree to which the South African procurement system may shift towards the centralised procurement pole. The drivers for the centralisation of procurement are primarily related to reducing costs, however as illustrated above centralised systems stifle long-term competition and consequently reduce the cost-effectiveness of a procurement system. It is evident that policy standards can be better provided for in centralised procurement systems whereas social goals may be harder to achieve in a centralised environment where cost-cutting is prioritised, but communication and transparency are undermined. Furthermore, the economic objectives of developing local SMEs appear to be achieved more effectively in a decentralised procurement system whereas evidence suggests SMEs are less confident in a centralised procurement system.

A decentralised procurement system promotes the section 217 principles better than a centralised procurement system. Perhaps the current issues experienced by the South African procurement authorities, primarily surrounding compliance and training, will be addressed more effectively through the centralisation of the regulatory powers governing public procurement and creating a single set of rules. It appears that the Constitution does not restrict the ability of the state to amend these regulatory powers, to the same extent as the state is required to amend the operational procurement powers. This is because at operational level, local government is constitutionally and autonomously empowered to control its procurement operations. Further, the Constitutional Court has indicated that local government's autonomous powers cannot be intruded upon and a municipality's competence cannot be diluted. The state is only able to determine norms and guidelines, in other words how procuring entities may conduct their procurement processes. Anything additional, which amounts to the management of a municipal procurement system, may be construed as a usurpation of powers. 
Finally, key legislation governing accountability within the public administration, the PFMA and MFMA, is irreconcilable with centralised procurement. This would place accounting officers in a difficult position if the aforementioned legislation were not to be amended accordingly. Evidently, there is a compelling argument to be made that significantly centralising public procurement operationally will be unlawful in terms of the current laws governing procurement, including the Constitution. Moving from the current decentralised model of conducting procurement to a centralised one may thus require amendments to the Constitution as well other legislation. 


\section{Bibliography}

\section{Books}

Bolton, P. 2007. The Law of Government Procurement in South Africa. Durban: Lexis Nexis.

Clark, F. and Lorenzoni, A. 1997. Applied Cost Engineering. New York: Marcel Dekker Inc.

Quinot, G. \& Arrowsmith, S. (Eds.). 2013. Public Procurement Regulation in Africa. Cambridge University Press.

Quinot, G. 2009. State Commercial Activity: A legal framework. Cape Town: Juta.

Sanchez Graells, A. 2016. Public Procurement and Competition: Some Challenges Arising from Recent Developments in EU Public Procurement Law. In Bovis, C. (Ed.). Research Handbook on European Public Procurement. Cheltenham: Edward Elgar Publishing, [online]. Available at: <http://researchinformation.bristol.ac.uk/files/47837444/Public_Procurement_and_Competition_revis ed_AUG_2015_.pdf> [Accessed 28-08-2016].

Sharma, K. 2009. Logistic Management: A Competitive Advantage for the New Millennium. New Delhi: Global India Publications.

Trepte, P. 2007. Regulating Procurement: Understanding the Ends and Means of Public Procurement Regulation. Oxford University Press.

\section{Case law}

Allpay Consolidated Investment Holdings (Pty) Ltd and Others v Chief Executive Officer of the South African Social Security Agency and Others [2013] ZACC 42.

City of Johannesburg Metropolitan Municipality v Gauteng Development Tribunal and Others 2010 (9) BCLR 859 (CC).

Ex parte Chairperson of the Constitutional Assembly: in re Certification of the Constitution of the Republic of South Africa 199619964 SA 744 (CC)

Maccsand (Pty) Ltd v City of Cape Town 20106 SA 63 (WCC).

Maccsand (Pty) Ltd v City of Cape Town 20127 BCLR 690 (CC).

Minister of Local Government, Environmental Affairs and Development Planning, Western Cape $v$ The Habitat Council; Minister of Local Government, Environmental Affairs and Development Planning, Western Cape v City of Cape Town 20144 SA 437 (CC). 
Steenkamp NO v Provincial Tender Board, Eastern Cape 20073 SA 121 (CC).

Tronox KZN Sands (Pty) Limited v KwaZulu-Natal Planning and Development Appeal Tribunal 2016 JDR 0179 (CC).

Wary Holdings (Pty) Ltd v Stalwo (Pty) Ltd and Another (CCT78/07) [2008] ZACC 12.

\section{Journal Articles}

Bolton, P. 2006. Government procurement as a policy tool in South Africa. Journal of Public Procurement 6(3):193-217.

Du Plessis, W. 2008. Legal mechanisms for cooperative governance in South Africa: Successes and failures. Southern African Public Law 23:87-110.

Humby, T. 2012. Maccsand: Intergovernmental relations and the doctrine of usurpation. Southern African Public Law 27:628-638.

Karjalainen, K., Kemppainen, K. \& van Raaij, E. 2009. Non-compliant work behaviour in purchasing: an exploration of reasons behind maverick buying. Journal of Business Ethics 85:245-261.

Van Wyk, J. 2012. Planning in all its (Dis)guises: Spheres of government, functional areas and authority. Potchefstroom Electronic Law Journal 15:287-318.

\section{Legislation}

Constitution of the Republic of South Africa, 1996.

Local Government: Municipal Finance Management Act 56 of 2003.

Preferential Procurement Policy Framework Act 5 of 2000.

Public Finance Management Act 1 of 1999.

State Tender Board Act 86 of 1968.

\section{Theses and dissertations}

De La Harpe, S.P. le R. 2009. Public Procurement Law: A Comparative Analysis. LLD Dissertation. University of South Africa. 
Kakwambi, J. 2012. Enhancing the contribution of small and medium-sized enterprises to local economic development in Oshakati Town, Namibia. Degree of Master of Public Administration. University of Stellenbosch.

Karjalainen, K. 2009. Challenges of purchasing centralisation- empirical evidence from public procurement. PhD Dissertation. Helsinki School of Economics, [online] March. Available at: <http://epub.lib.aalto.fi/pdf/diss/a344.pdf> [Accessed 20-082016].

\section{Reports}

Auditor-General Consolidated General Report on the audit outcomes of local government MFMA 2014/2015.

Eastern Cape Provincial Treasury 2014/2015 Annual Report.

KZN Provincial Treasury 2014/15 Annual Report.

Leenders, M. 1998. The problem with purchasing savings. London.

Limpopo Provincial Treasury 2014/2015 Annual Report.

OECD, 2000. Centralised and Decentralised Public Procurement. SIGMA Papers, [online] OECD Publishing. Available at: <http://dx.doi.org/10.1787/5kml60w5dxr1en> [Accessed 14-08-2016].

Phillips, W., Harland, C. \& Telgen, J. 2008. Building public procurement capacity \& capability. International Research Study on Public Procurement, [online]. Available at:

<http://www.unpcdc.org/media/12355/int|\%20resarch\%20study\%20of\%20pp\%20200 8.pdf $>$ [Accessed 19-08-2016].

Quinot, G. 2014. An Institutional Legal Structure for Regulating Public Procurement in South Africa. APLU, [online] March 2014. Available at:

$<$ http://africanprocurementlaw.org/wp-content/uploads/2016/01/OCPO-Final-ReportAPPRRU-Web-Secure.pdf> [Accessed 21-08-2016].

\section{Online sources}

Central City Improvement District, 2015. About. Cape Town CCID, [online]. Available at: <http://www.capetownccid.org> (Accessed 02/08/2016).

Education \& Training Unit, 2005. Integrated Development Planning for Local Government. ETU, [online]. Available at: <http://www.etu.org.za/toolbox/docs/localgov/webidp.html> [Accessed 01-08-2016] 
Education \& Training Unit, 2005. Guide for Municipal Service Delivery. ETU, [online]. Available at: <http://www.etu.org.za/toolbox/docs/localgov/munservice.html> [Accessed 01-08-2016].

European Commission on Enterprise and Industry, 2014. Small Businesses Act Fact Sheet: Bulgaria. European Commission, [online]. Available at:

<http://ec.europa.eu/DocsRoom/documents/16121/attachments/5/translations/en/ren ditions/native $>$ [Accessed 18-08-2016].

Minister of Finance South Africa 2016 Budget Speech Report No: 17 of 2016.

National Treasury, [online]. Available at:

<http://www.treasury.gov.za/documents/national\%20budget/2016/speech/speech.pdf $>$ [Accessed 01-08-2016].

Hanks, J., 2008. Sustainable Public Procurement in South Africa. IISD, [online].

Available at: <https://www.iisd.org/pdf/2008/spp_south_africa.pdf> [Accessed 18-082016].

Irish Small and Medium Enterprises Association, 2013. Public procurement issues facing Irish SMEs - Discussion document. ISME, [online]. Available at: $<$ http://isme.ie/assets/13304-ISME-doc-Public-Procurement-1.pdf> [Accessed 01-082016].

National Treasury, 2015. Public sector supply chain management review. National Treasury, [online]. Available at:

<http://www.treasury.gov.za/publications/other/SCMR\%20REPORT\%202015.pdf> [Accessed 01-08-2016].

National Treasury, 2016. SCM Review Update. National Treasury, [online]. Available at:

<http://www.treasury.gov.za/publications/other/SCM\%20Review\%20Update\%20201 6.pdf> [Accessed 01-08-2016]. 